\title{
Cell therapy with autologous bone marrow mononuclear stem cells is associated with superior cardiac recovery compared with use of nonmodified mesenchymal stem cells in a canine model of chronic myocardial infarction
}

\author{
Myrielle Mathieu, DVM, ${ }^{\mathrm{a}}$ Jozef Bartunek, MD, PhD, ${ }^{\mathrm{b}, \mathrm{c}}$ Bachar El Oumeiri, MD, ${ }^{\mathrm{d}}$ Karim Touihri, MD, ${ }^{\mathrm{a}}$ \\ Ielham Hadad, MS, ${ }^{\mathrm{a}}$ Philippe Thoma, MD, ${ }^{\mathrm{e}}$ Thierry Metens, MS, PhD, ${ }^{\mathrm{e}}$ Agnes Mendes da Costa, DVM, ${ }^{\mathrm{a}}$ \\ Maryam Mahmoudabady, MD, ${ }^{\mathrm{a}}$ Dominique Egrise, MS, PhD, ${ }^{\mathrm{f}}$ Didier Blocklet, MD, ${ }^{\mathrm{f}}$ Naïma Mazouz, MS, \\ $\mathrm{PhD},{ }^{\mathrm{g}}$ Robert Naeije, MD, PhD, ${ }^{\mathrm{a}}$ Guy Heyndrickx, $\mathrm{MD}, \mathrm{PhD},{ }^{\mathrm{b}, \mathrm{h}}$ and Kathleen McEntee, DVM, $\mathrm{PhD}^{\mathrm{a}}$
}

\begin{abstract}
Objective: Stem cell therapy can facilitate cardiac repair in infarcted myocardium, but the optimal cell type remains uncertain. We conducted a randomized, blind, and placebo-controlled comparison of autologous bone marrow mononuclear cell and mesenchymal stem cell therapy in a large-animal model of chronic myocardial infarction.
\end{abstract}

Methods: Eleven weeks after coronary ligation, 24 dogs received intramyocardial injections of mononuclear cells ( $227.106 \pm 32.106$ cells), mesenchymal stem cells ( $232.106 \pm 40.106$ cells), or placebo $(\mathrm{n}=8$ per group). Cardiac performance and remodeling were assessed up to 16 weeks' follow-up.

Results: At echocardiographic analysis, the wall motion score index showed a sustained improvement after mononuclear cell transfer (from $1.8 \pm 0.1$ to $1.5 \pm 0.07$ ) and a moderate late improvement after mesenchymal stem cell transfer (from $1.9 \pm 0.08$ to $1.7 \pm 0.1$ ). After mononuclear cell transfer, end-systolic elastance increased (from $2.23 \pm 0.25$ to $4.42 \pm 0.55 \mathrm{~mm} \mathrm{Hg} / \mathrm{mL}$ ), infarct size decreased (from $13 \% \pm 0.67 \%$ to $10 \% \pm 1.17 \%$ ), $\mathrm{N}$-terminal B-type natriuretic propeptide level decreased (from $608 \pm 146$ to $353 \pm 118 \mathrm{pmol} / \mathrm{L}$ ), and relative wall area and arterial density increased. Vascular endothelial growth factor receptor 2 expression was upregulated in the border zone. No change in cardiac contractility or histologic parameters was noted in the mesenchymal stem cell group.

Conclusion: In a canine model of chronic myocardial infarction, bone marrow mononuclear cell transfer is superior to mesenchymal stem cell transfer in improvement of cardiac contractility and regional systolic function and reduction in infarct size and plasma $\mathrm{N}$-terminal B-type natriuretic propeptide level. Functional improvement is associated with a favorable angiogenic environment and neovascularization.

Cell therapy with bone marrow-derived stem cells has been investigated to facilitate cardiac repair after ischemic injury with beneficial effects. ${ }^{1}$ Most clinical studies use the entire bone marrow mononuclear cell (BMNC) fraction $^{2-7}$ with the rationale that the functional effect depends on the equilibrium between the multiple cell types, and by using a large panel of precursors, no potentially beneficial cell type is

From the Departments of Physiopathology, ${ }^{\text {a }}$ Radiology and Medical Imaging, ${ }^{\mathrm{e}}$ and Radio-Isotope Imaging, ${ }^{\mathrm{f}}$ Faculty of Medicine, UBL, Brussels, Belgium; the Cardiovascular Center, ${ }^{\mathrm{b}}$ OLV, Aalst, Belgium; the Faculty of Biomedical Engineering, ${ }^{\text {c }}$ TU Eindhoven, The Netherlands; the Cardio-Thoracic Surgery Department ${ }^{d}$ and the Department of Physiology, ${ }^{\mathrm{h}}$ Saint-Luc University Hospital, UCL, Brussels, Belgium; and Cardio ${ }^{3}$ BioSciences, ${ }^{\mathrm{g}}$ Braine L'Alleud, Belgium.

This work was supported by the Foundation for Cardiac Surgery, Brussels, Belgium. Received for publication Aug 27, 2008; revisions received Nov 25, 2008; accepted for publication Dec 25, 2008; available ahead of print Feb 17, 2009.

Address for reprints: Myrielle Mathieu, DVM, ULB-Erasme, 808 route de Lennik CP604, 1070 Brussels, Belgium (E-mail: myrielle.mathieu@ulb.ac.be).

J Thorac Cardiovasc Surg 2009; 138:646-53

$0022-5223 / \$ 36.00$

Copyright (c) 2009 by The American Association for Thoracic Surgery

doi:10.1016/j.jtcvs.2008.12.031 omitted. This is supported by the results of recent doubleblind and placebo-controlled trials in patients with acute myocardial infarction (MI), ${ }^{4,6}$ and this strategy is applied also in ongoing trials in patients with chronic ischemic heart failure. On the other hand, culture-expanded mesenchymal stem cells (MSCs) are characterized by multilineage differentiation potential, notably in cardiomyocytes and endothelial cells. ${ }^{8-11}$ Moreover, their immunoprivileged features might allow allogenic use. ${ }^{12}$ Although this might offer several advantages over the mononuclear cell fraction, there are no data comparing the efficacy of both cell types in chronic models of MI. In addition, previous experimental studies only used a limited set of load-dependent functional surrogate end points. Thus far, an integrative assessment of interventional outcome on left ventricular (LV) function, contractility, infarct size, and remodeling is lacking.

Therefore we conducted a randomized, investigatorblinded, and placebo-controlled study with multimodality assessment of autologous BMNC and MSC therapy in a canine model of chronic MI. 


$\begin{array}{ll}\text { Abbreviations and Acronyms } \\ \text { Ang } & =\text { angiopoietin } \\ \text { BMNC } & =\text { bone marrow mononuclear cell } \\ \text { Ct } & =\text { cycle threshold } \\ \text { Ees } & =\text { end-systolic elastance } \\ \text { LV } & =\text { left ventricular } \\ \text { MI } & =\text { myocardial infarction } \\ \text { MRI } & =\text { magnetic resonance imaging } \\ \text { MSC } & =\text { mesenchymal stem cell } \\ \text { RTQ-PCR } & =\text { real-time quantification polymerase } \\ & \text { chain reaction } \\ \text { SDF-1 } & =\text { stromal cell-derived factor } 1 \\ \text { TEK } & =\text { angiopoietin } 1 \text { and } 2 \text { receptor } \\ \text { VEGF } & =\text { vascular endothelial growth factor } \\ \text { VEGFR } & =\text { vascular endothelial growth factor } \\ & \text { receptor } \\ \text { WMS } & =\text { wall motion score }\end{array}$

\section{MATERIALS AND METHODS}

The study was approved by the institutional ethics committee for animal research, and all animals received humane care in compliance with the "Guide for the care and use of laboratory animals" (http://www.nap.edu/ catalog/5140.html).

\section{Animals and MI}

MI was caused by ligation of the left circumflex coronary artery, its marginales, or both in dogs (CEDS, Mézilles, France; $13.7 \pm 0.4 \mathrm{~kg} ; 10-15$ months old). After intravenous premedication with $0.1 \mathrm{mg} / \mathrm{kg}$ of midazolam and $0.1 \mu \mathrm{g} / \mathrm{kg}$ sufentanil, anesthesia was induced with 3 to $4 \mathrm{mg} / \mathrm{kg}$ intravenous propofol and maintained with isoflurane $(1.5 \%-2 \%)$. Animals were ventilated with a fraction of inspired oxygen of 1, a respiratory rate of 12 breaths $/ \mathrm{min}$, and a tidal volume of 12 to $15 \mathrm{~mL} / \mathrm{kg}$. Lactate-Ringer's solution was infused at $10 \mathrm{~mL} \cdot \mathrm{kg}^{-1} \cdot \mathrm{h}^{-1}$, and sufentanil was infused at $1 \mu \mathrm{g}$. $\mathrm{kg}^{-1} \cdot \mathrm{h}^{-1}$. After a left thoracotomy, MI was created by means of surgical ligation of the left circumflex artery, its marginales, or both, with special care to obtain the same infarction extent despite anatomic specificities. Severe ventricular arrhythmias during and after the procedure were treated with 2 to $4 \mathrm{mg} / \mathrm{kg}$ intravenous lidocaine over a period of 2 minutes followed by an infusion of $75 \mu \mathrm{g} \cdot \mathrm{kg}^{-1} \cdot \mathrm{min}^{-1}$. After surgical intervention, buprenorphine ( $10 \mu \mathrm{g} / \mathrm{kg}$ administered intramuscularly 3 times daily) and cephalexin $(20 \mathrm{mg} / \mathrm{kg}$ administered subcutaneously twice daily) were administered for 48 hours. Only animals with an echocardiographic wall motion score (WMS) index of greater than 1.6 one week after ligation entered the study $(\mathrm{n}=24)$.

\section{Bone Marrow Cell Preparation}

Autologous bone marrow MSCs, harvested in the iliac crest of each dog the day of coronary ligation, were culture expanded as described previously $^{13}$; the samples were immediately treated with a mix (1:1) of dimethyl sulfoxide and hydroxyethyl starch solution (6\% final concentration) and frozen at $-80^{\circ} \mathrm{C}$ until processing. Four weeks after ligature, samples were thawed, and marrow was plated onto T75 collagen-treated culture flasks in standard growth media to remove nonadherent cells. The plastic-attached cells were culture expanded for 3 to 5 weeks with media containing DMEM (Invitrogen, Merelbeke, Belgium), 20\% fetal bovine serum (Hyclone, Logan, Utah), $100 \mathrm{mmol} / \mathrm{L} \mathrm{L}$-ascorbic acid (Sigma-Aldrich, St Louis, Mo), and $5 \mathrm{mg} / \mathrm{mL}$ human leukemia inhibitor factor (Sigma-Aldrich). After ex- pansion, MSCs were frozen at $-80^{\circ} \mathrm{C}$ until use. Before injection, cells were washed with the culture medium and phosphate-buffered saline. The day of injection, autologous BMNCs prepared from the bone marrow harvested the day of injection were enriched with the use of the Ficoll-Hypaque centrifugation procedure (Lymphoprep, Oslo, Norway). Marrow was diluted 1:4 with Hank's medium and centrifuged on a Ficoll density gradient (at $600 \mathrm{~g}$ for 30 minutes) to isolate the mononuclear cells. The placebo medium was phosphate-buffered saline.

Preference was given to the use of canine antibodies to characterize the cells. However, when canine antibodies were commercially unavailable, human antibodies were used. More specifically, canine MSCs and BMNCs were analyzed by means of FACS after incubation with anti-human CD44, CD166, CD14, CD13, CD90, CD105, CD73 (SH3), CD71 (SH3), CD45, Stro-1, CD133, CD117, HLA class I, and HLA class II antibodies conjugated with fluorescein isothiocyanate or phycoerythrin. The CD14 and CD44 antibodies are known to cross-react with dog cells. Dog cells were also analyzed with anti-canine CD34 antibodies conjugated with phycoerythrin. Viability was analyzed by using Trypan blue staining.

\section{Experimental Design}

Animals were randomized into 3 groups ( $\mathrm{n}=8$ per group): the placebo, BMNC, and MSC groups. Cells were injected $11.2 \pm 0.63$ weeks after coronary ligation. A total volume of $4 \mathrm{~mL}$ of cells or placebo was injected through a thoracotomy tangentially into the infarct and border zones over approximately 20 injections of approximately $0.2 \mathrm{~mL}$ with a 27 -gauge needle. Cells were injected in parallel lines extending from healthy tissue to the opposite border zone (until $1.5 \mathrm{~cm}$ in healthy tissue). Lines were between 0.5 and $1 \mathrm{~cm}$ apart, and on the lines, injection points were also between 0.5 and $1 \mathrm{~cm}$ apart. A total of $227 \pm 32 \times 10^{6}$ MSCs and $232 \pm 40 \times$ $10^{6} \mathrm{BMNCs}$ were injected. Echocardiographic analysis was performed before MI and repeated 1 and 2 weeks before cell injection (baseline), as well as 8, 9 (9 weeks), and 16 weeks after cell injection. Pressure-volume loops were determined 1 week before cell injection (baseline) and at 9 weeks' follow-up. Cardiac magnetic resonance imaging (MRI) was performed at baseline and 16 weeks' follow-up. Venous blood samples were collected before cell injection and 2, 4, 6, 8, and 16 weeks after cell injection. At 17 weeks' follow-up, dogs were killed, and tissue samples were taken for postmortem analyses.

The following end points were analyzed. Cardiac contractility was assessed from the LV end-systolic elastance (Ees), regional LV function was assessed from the WMS index at echocardiographic analysis, infarction size was measured by using late enhancement imaging at MRI, the humoral marker of LV dysfunction was assessed by means of plasma concentration of N-terminal B-type natriuretic propeptide (NT-proBNP), remodeling was assessed based on the relative LV wall area at macromorphometry, neovascularization was assessed based on vascular density at immunohistochemistry, and transcriptional profile of angiogenic signaling was assessed by means of real-time quantification polymerase chain reaction (RTQ-PCR).

\section{Echocardiographic Analysis}

Echocardiographic analysis (Vivid 5; GE, Brussels, Belgium) was performed in awake dogs, with recordings in standard windows according to recommendations. ${ }^{14}$ The WMS index was assessed by using the 16 -segment model. ${ }^{15}$ All images were recorded and analyzed offline as a consensus of 2 experienced ultrasonographers $(\mathrm{KM}$ and $\mathrm{JB})$ blinded to the treatment assignment.

\section{Pressure-Volume Loops}

Pressure-volume loops were obtained through catheterization in anesthetized closed-chest dogs. They were generated with a LV conductance catheter (Millar Instruments, Houston, Tex) and IOX software (EMKA Technologies, Paris, France). Ees of the left ventricle, a load-independent 
parameter, was measured during temporary occlusion of the inferior vena cava during respiratory arrest. A linear regression analysis of the end-systolic pressure-volume points during transient preload reduction determined the slope (Ees) of the end-systolic pressure-volume relationship. ${ }^{16}$

\section{MRI}

Infarct size was assessed by using the 1.5 -Tesla clinical MRI scanner (Achieva 1.5T; Phillips Best, The Netherlands) with a 2-element phased array coil placed over the chest (Sense Flex-M Coil; Philips, Brussels, Belgium). After contrast-enhanced images were acquired, raw images were processed by means of manual outlining of the endocardial-epicardial and infarct borders. Total infarct volume was calculated as the summation of the contrast-enhanced volumes from all contrast-enhanced MRI images. Relative MI size was determined as the ratio of infarct volume to LV wall volume times 100 .

\section{Blood Biology}

NT-proBNP levels were measured by means of enzyme-linked immunosorbent assay (VETSIGN Canine CardioSCREEN Nt-proBNP Test VC4010; Guildhay Limited, Guildford, England).

\section{Macromorphometry}

After death, hearts were sectioned into 8-mm-thick short-axis slices and digitally photographed. By using image J (National Institute of Health, http:// rsb.info.nih.gov/ij/), LV endocardial and epicardial borders were traced. Relative LV wall area was evaluated in apical, mid, and basal slices as (Epicardial area-Endocardial area $) \times 100 /$ Epicardial area and averaged.

\section{Immunohistochemistry}

Paraffin-embedded formalin-fixed specimens from the infarct, border, and remote zones were prepared in 5- $\mu$ m-thick sections. Endothelial cells were stained with anticaveolin-1 antibody (sc-984; Santa Cruz Biotechnology, Inc, Santa Cruz, Calif). Sections incubated with nonimmune serum were used as negative controls. Microvessels (diameter $<20 \mu \mathrm{m}$ ) were counted on 10 different $\times 400$ randomly selected fields from each zone, and the density of arterial vessels (diameter $>20 \mu \mathrm{m}$ ) was semiquantified by using a relative gradient between 0 and 2 .

\section{RTQ-PCR}

Total RNA of snap-frozen specimens (placebo and MSC groups, $\mathrm{n}=7$; BMNC group, $\mathrm{n}=6$ ) from the infarct, border, and remote zones of each group was extracted with Trizol (Invitrogen), and its concentration was adjusted to $0.25 \mu \mathrm{g} / \mu \mathrm{L}$. After first-strand cDNA synthesis, Sybr Green RTQPCR was performed (Icycler; Bio-Rad Laboratory, Nazareth, Belgium). Primers were designed to recognize canine cDNA sequences of vascular endothelial growth factor (VEGF) and its receptors (VEGFR1 and VEGFR2), angiopoietin 1 (Ang1) and Ang2, their receptor (TEK), and stromal cell-derived factor 1 ( $S D F 1)$. Abbelson was used as a housekeeping gene. Statistical analysis was carried out by using the differences between the cycle thresholds ( $\mathrm{Ct} ; \Delta C t=C t$ gene of interest $-C t$ housekeeping gene). Relative gene expression values were obtained by using the $\Delta \Delta \mathrm{Ct}$ method ( $\Delta C t$ sample $-\Delta C$ t calibrator ) with placebo as the calibrator. The conversion of $\Delta \Delta \mathrm{Ct}$ to relative gene expression is a result of fold induction: $2^{-\Delta \Delta \mathrm{Ct}} \cdot{ }^{17}$

\section{Statistics}

All continuous values are expressed as means \pm standard error of the mean, all reported $P$ values are 2 -sided, and statistical significance is assessed at the $5 \%$ level. The normality of distribution was tested with a Shapiro-Wilk test. For normal data, differences were tested by using 2way analysis of variance (group and time) for repeated measures with an interaction term, followed by Scheffe post-hoc tests when overall significance was detected. When the Shapiro-Wilk test failed, differences within the groups (repeated measures) were analyzed by using a Friedman test, and differences between groups were analyzed by using a Kruskal-Wallis test. For baseline characteristics, macromorphometry, histologic data, and RTQPCR, differences between groups were tested by using 1-way analysis of variance, followed by Scheffe post-hoc tests when overall significance was detected. When the Shapiro-Wilk test failed, differences between groups were tested by using a Kruskal-Wallis test.

\section{RESULTS \\ Baseline Characteristics}

BMNCs showed uniformly CD14 and CD44 markers, whereas only $3 \%$ of cells were $\mathrm{CD} 34^{+}$and $3 \%$ were $\mathrm{CD}_{166}{ }^{+}$. MSCs were positive for CD166 (42\%) and CD44 (84\%). Canine MSCs and BMNCs were negative for all the other markers tested, but a lack of cross-reactivity might explain the negative results. Morphology of BMNCs and MSCs was comparable with that of similar cells in other species. The percentage viability was $99 \% \pm 0.05 \%$ for BMNCs and $98.4 \% \pm 0.51 \%$ for MSCs.

Coronary ligation resulted in a mean infarct size of $12.9 \%$ $\pm 0.7 \%$, a mean WMS index of $1.8 \pm 0.06$, and a mean Ees of $2.3 \pm 0.26 \mathrm{~mm} \mathrm{Hg} / \mathrm{mL}$. Cardiac function baseline characteristics before cell injection, such as infarct size (placebo group, $12 \% \pm 1 \%$ enhanced area; BMNC group, $13 \% \pm$ $2 \%$ enhanced area; MSC group, $14 \% \pm 1 \%$ enhanced area; $P=.460$ ), Ees (placebo group, $2.7 \pm 0.2 \mathrm{~mm} \mathrm{Hg} /$ $\mathrm{mL}$; BMNC group, $2.2 \pm 0.3 \mathrm{~mm} \mathrm{Hg} / \mathrm{mL}$; MSC group, $2.1 \pm 0.7 \mathrm{~mm} \mathrm{Hg} / \mathrm{mL} ; P=.339$ ), and WMS (placebo group, $1.7 \pm 0.1 ;$ BMNC group, $1.8 \pm 0.1$; MSC group, $1.9 \pm 0.1$; $P=.571$ ), were not different between groups.

\section{Effects of Cell Therapy on Cardiac Function}

Ees increased after BMNC transfer but remained unchanged in the placebo and MSC groups (Figure 1). The volume-axis intercept of the end-systolic pressure-volume relationship remained unchanged in the 3 groups (data not shown). Bidimensional echocardiographic analysis revealed a sustained reduction in the WMS index in the BMNC group at 9 and 16 weeks' follow-up compared with the value at baseline. In contrast, only a mild late decrease in the WMS index was noted in the MSC group, whereas no change was observed in the placebo group (Figure 2). No significant changes in the $\mathrm{LV}$ ejection fraction were noted (change: $-1.2 \% \pm 3 \%$ in the placebo group, $+3.4 \% \pm 3 \%$ in the BMNC group, and $+0.4 \% \pm 2 \%$ in the MSC group). Nevertheless, improved regional wall motion and contractility after cell therapy was associated with a decrease in plasma NT-proBNP levels in the BMNC group, whereas no changes were observed in the placebo and MSC groups (Figure 3).

\section{Effects of Cell Therapy on Infarct Size and LV Remodeling}

As shown in Figure 4, infarct size, as assessed from the extent of late hyperenhancement at MRI, increased in the placebo group and decreased in the BMNC group. No change 

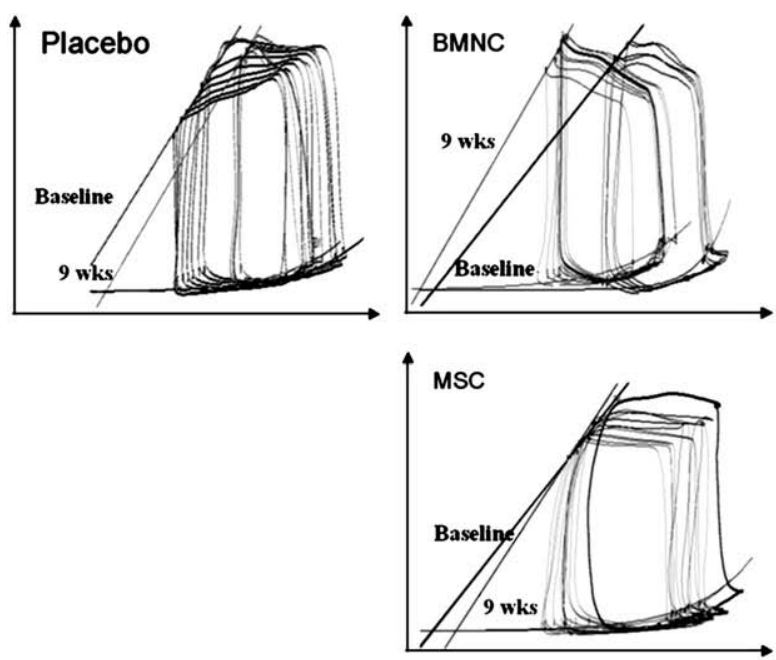

A

FIGURE 1. Left ventricular contractility. A, Representative pressure-volume loops during vena caval occlusion in each group at baseline and 9 weeks' follow-up. Note the increased end-systolic elastance (Ees) after bone marrow mononuclear cell $(B M N C)$ transfer. B, End-systolic elastance at baseline and 9 weeks' follow-up in the placebo, bone marrow mononuclear cell, and mesenchymal stem cell (MSC) groups.

was observed in the MSC group. Relative LV wall area, measured postmortem by means of macromorphometry, was higher in the BMNC group compared with that seen in the placebo and MSC groups (Figure 5).

\section{Vascular Density and Gene Expression Analysis}

The density of microvessels (diameter $<20 \mu \mathrm{m}$ ) was similar between the groups (data not shown). However, a higher density of vessels over $20 \mu \mathrm{m}$ was observed in the infarct tissue after BMNC transfer compared with that seen in the MSC group (Figure 6). In addition, VEGFR2 message levels were increased and $T E K$ message levels tended to increase in the border zone after BMNC transfer compared with that seen in other groups (Figure 7, $A$ and $B$ ). SDF1 message levels tended to be higher in the remote and border zones for the

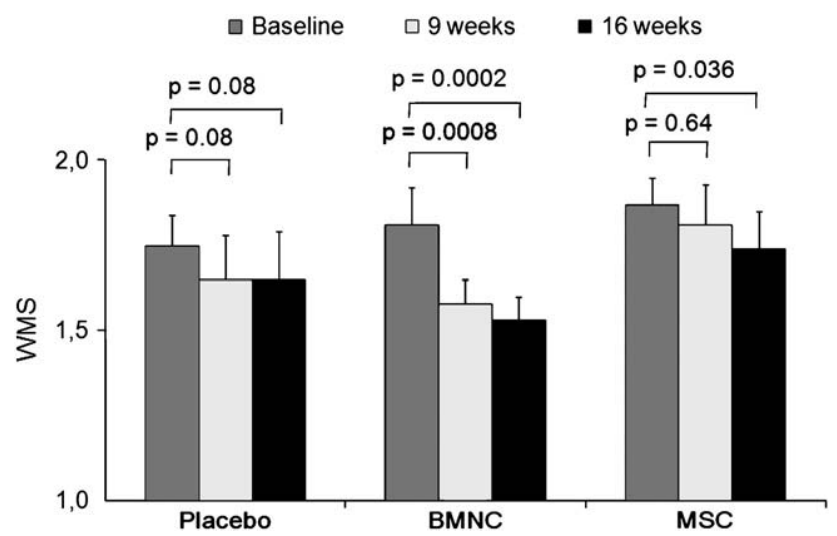

FIGURE 2. Left ventricular regional systolic function. The wall motion score $(W M S)$ index at echocardiographic analysis at baseline and 9 and 16 weeks' follow-up in the placebo, bone marrow mononuclear cell $(B M N C)$, and mesenchymal stem cell (MSC) groups is shown.
BMNC group compared with those seen in the MSC group (Figure $7, C$ ). There were no changes in expression of $V E G F$, VEGFR1, Ang1, and Ang2 (data not shown). Note, TEK message levels were inversely related to WMS index (Figure 7,D), and the $S D F 1$ levels correlated with both $\operatorname{VEGFR} 2(r=0.55, P<.001)$ and TEK $(r=0.51, P<.001)$.

\section{DISCUSSION}

The present randomized, blinded, and placebo-controlled large-animal study used multimodality assessment to compare the efficacy of autologous BMNCs and nonmodified MSCs for the treatment of chronic MI. Direct myocardial injections of BMNCs were associated with superior improvement in

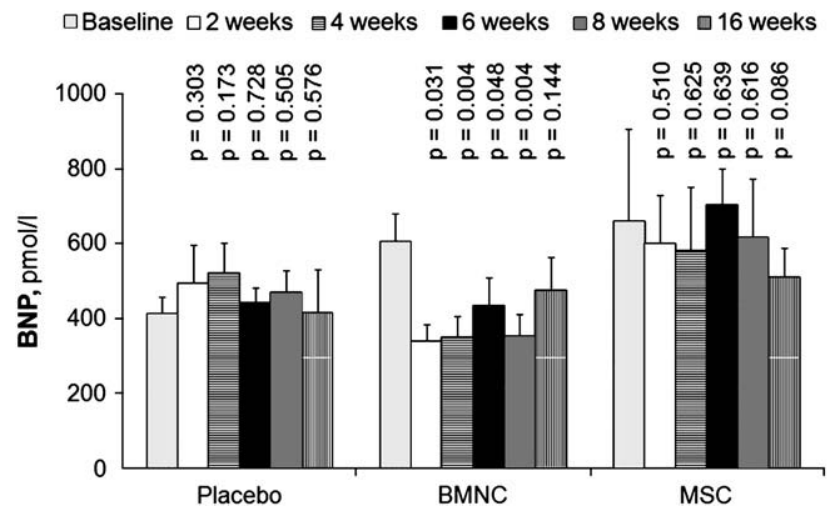

FIGURE 3. Time course of N-terminal B-type natriuretic propeptide $(B N P)$. Plasma N-terminal B-type natriuretic propeptide levels decreased at $2,4,6$, and 8 weeks' follow-up in the bone marrow mononuclear cell $(B M N C)$ group compared with baseline values and remained unchanged in the other 2 groups. $P$ values are shown versus baseline values. MSC, Mesenchymal stem cell. 
$\square$ Baseline

-16 weeks

MI, \%

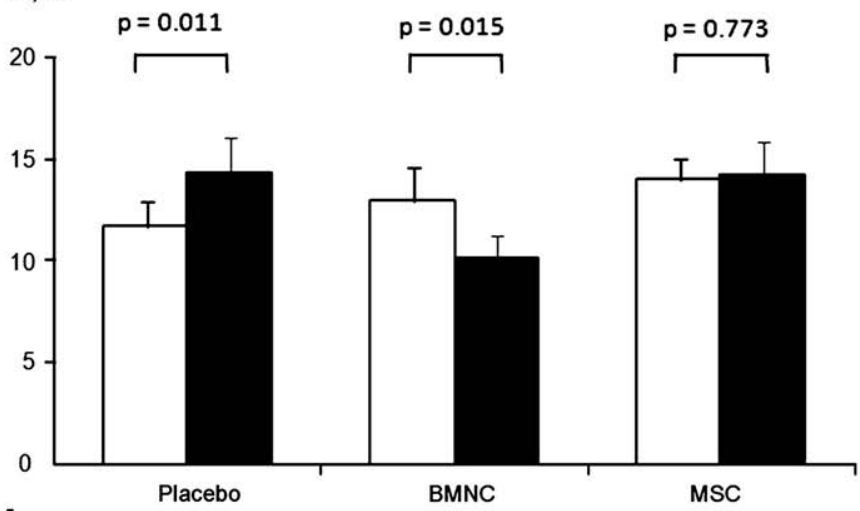

A
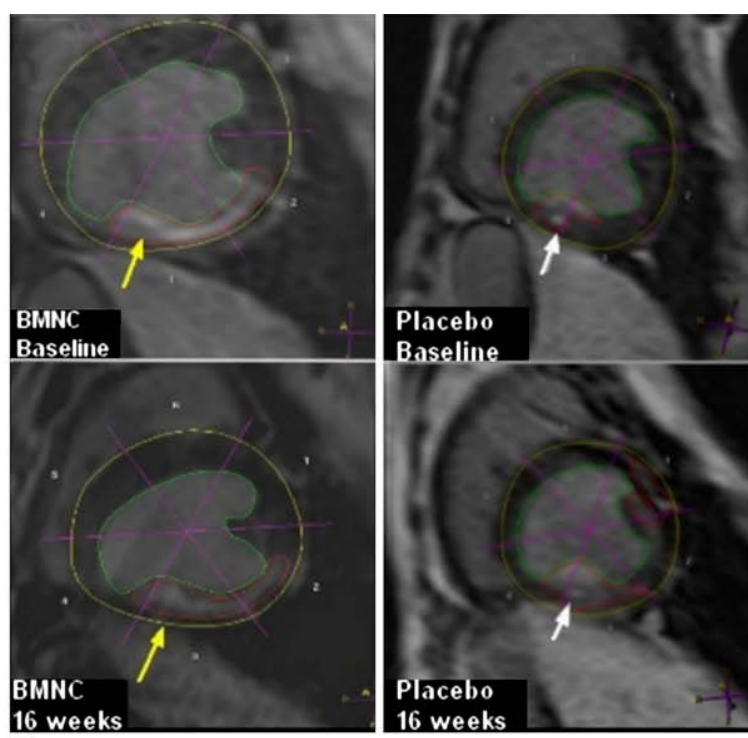

Baselime

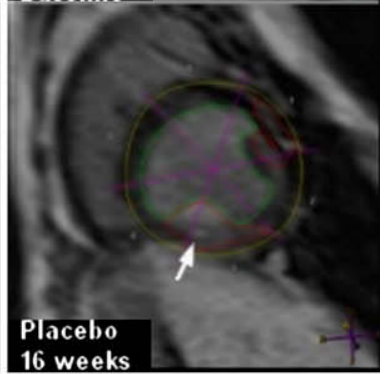

B

FIGURE 4. Left ventricular infarct size. A, Infarct size (myocardial infarction $[M I]$ as a percentage) determined by means of contrast-enhanced magnetic resonance imaging at baseline and 16 weeks' follow-up in the placebo, bone marrow mononuclear cell (BMNC), and mesenchymal stem cell (MSC) groups is shown. B, Left, Representative example before and after bone marrow mononuclear cell transfer. Note a reduction in the late enhancement at follow-up (yellow arrow). Right, Late enhancement intensity remained unchanged in the placebo-treated animal, and infarct size increased (white arrow).

cardiac contractility and LV regional function, as well as reduction in infarct scarring, compared with that seen after MSCs. This functional improvement was paralleled by reverse remodeling and neovascularization.
Among various autologous cell types, most of the preclinical and clinical trials have tested BMNCs. ${ }^{1-6}$ Their choice was based on the postulate that by using the entire mononuclear fraction, no potentially beneficial cell type was omitted
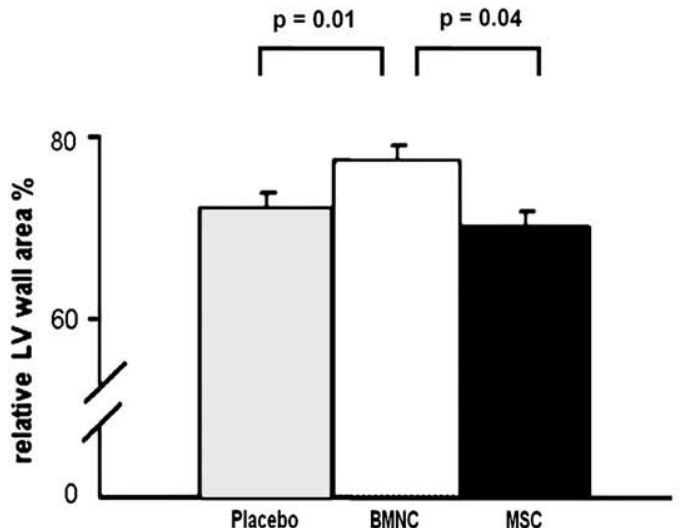

A
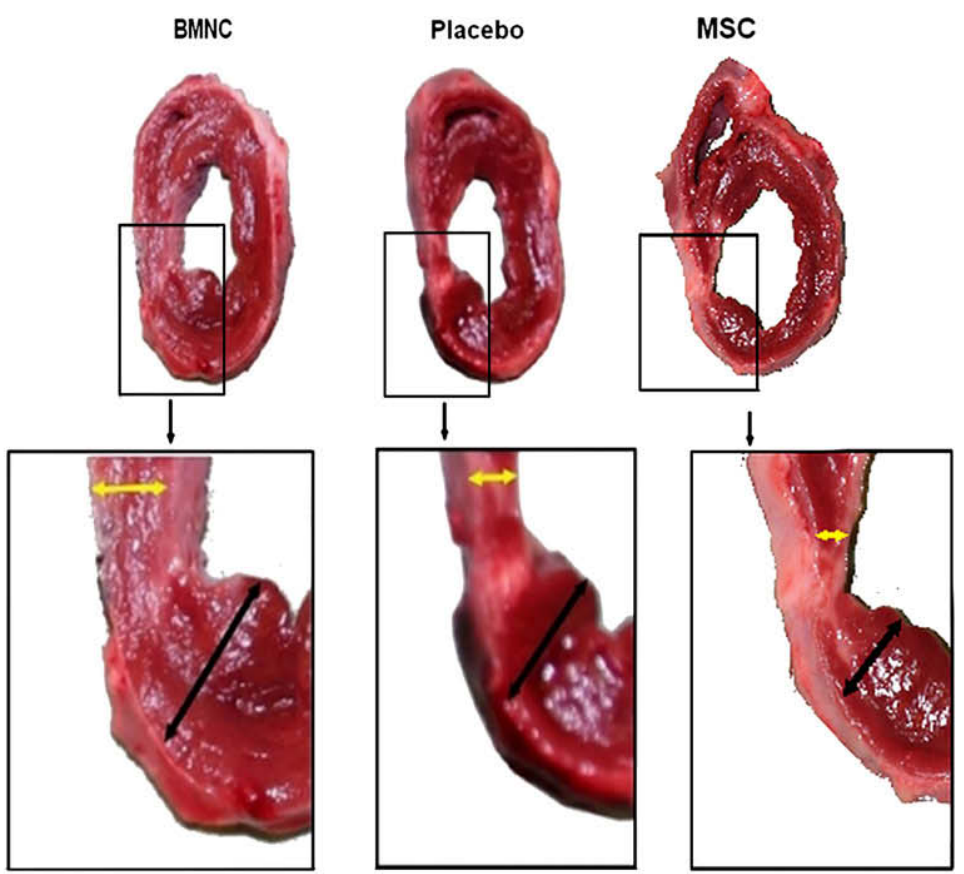

B

FIGURE 5. Left ventricular $(L V)$ remodeling. A, Relative left ventricular wall area at macromorphometry in the placebo, bone marrow mononuclear cell $(B M N C)$, and mesenchymal stem cell (MSC) groups is shown. B, Representative macromorphometric analysis in the placebo, bone marrow mononuclear cell, and mesenchymal stem cell groups is shown. Wall thickness in the infarct zone (yellow arrows) and in the border zone (black arrows) is greater in the bone marrow mononuclear cell-treated animal compared with that seen in the placebo-treated and mesenchymal stem cell-treated animals. 

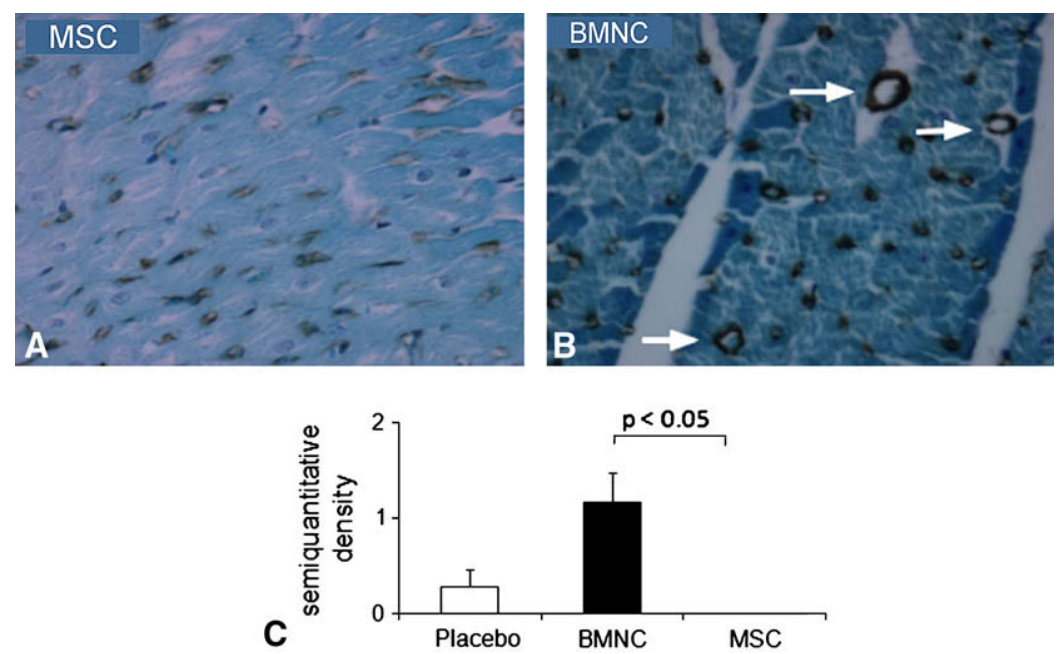

FIGURE 6. Vascular density. Upper panels show representative immunostaining with anticaveolin 1 in a bone marrow mononuclear cell (BMNC; A)- and mesenchymal stem cell $(M S C$; B)-treated animal. (Original magnification $\times 40$ ). White arrows show vessels larger than $20 \mu \mathrm{m}$. C, Semiquantitative assessment of arterial vessels $(>20 \mu \mathrm{m})$ density in the infarct zone of the placebo, bone marrow mononuclear cell, and mesenchymal stem cell groups.

and that the functional response would depend on the equilibrium between cell types. This postulate is supported by the cellular crosstalk between multiple cell types required during embryonic vascular development. ${ }^{18}$ Regardless of the controversy over whether transplanted BMNCs $\mathrm{do}^{1}$ or do not $^{19}$ transdifferentiate, a number of preclinical and clinical studies have demonstrated that administration of BMNCs can improve cardiac function or perfusion early after $\mathrm{MI}^{2-4,6}$ or lead to reduction in infarct size. ${ }^{5}$ Nevertheless, the potential of bone marrow cells in the setting of ischemic congestive heart failure was studied only in small, nonrandomized clinical trials and remains unknown. ${ }^{20-23}$

An alternative to the mononuclear cell fraction is the enrichment for a specific cell population, such as hematopoietic cells or MSCs. In both strategies the hypothetical benefit is the retention of cells with well-defined biologic properties in a much higher dose that could be achieved if given as a part of the mononuclear cell fraction. MSCs appear to offer an additional advantage by displaying multilineage potential ${ }^{11}$ and cytokine production in response to
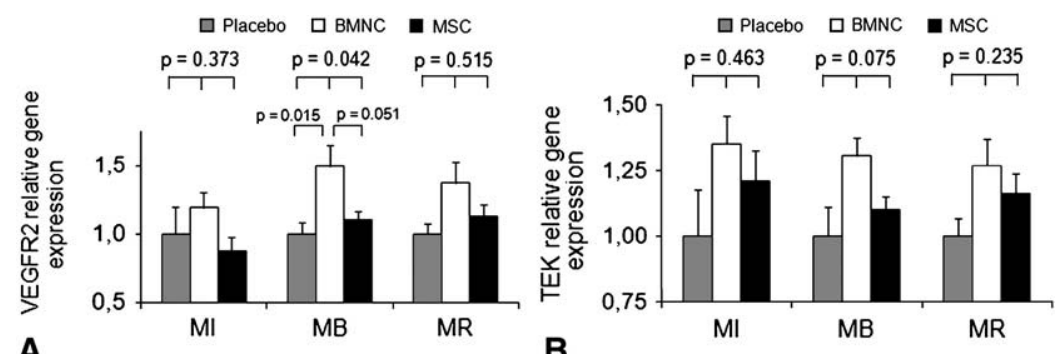

A
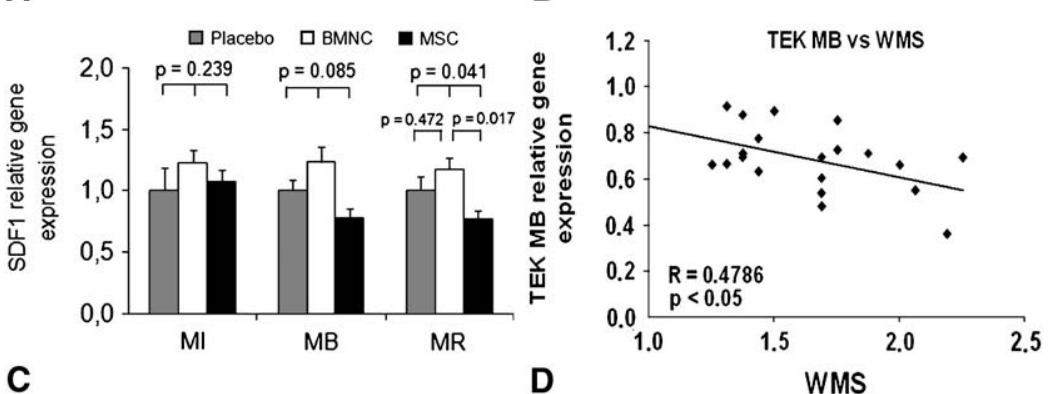

FIGURE 7. Angiogenic factors. A, B, and C, Relative gene expression of vascular endothelial growth factor receptor 2 (VEGFR2), angiopoietin-1 and angiopoietin-2 receptor (TEK), and stromal cell-derived factor 1 ( $S D F 1)$ in infarct $(M I)$, border $(M B)$, and remote $(M R)$ areas of the placebo, bone marrow mononuclear cell, and mesenchymal stem cell groups. The mean value for the placebo group is represented as 1 , and the values of treated dogs are adjusted accordingly. D, Scatterplots of TEK-relative gene expression in the border zone (y-axis) versus the WMS index (x-axis). The regression equation, its coefficient of correlation $(r)$, and significances are shown. 
various stimuli. Furthermore, their immunologic privilege makes them an ideal candidate for the regenerative therapies with a potential off-shelf use. ${ }^{12}$ In a rat or swine model of myocardial ischemia-reperfusion injury, allogenic MSCs contributed to neovascularization and myogenesis and improved LV ejection fraction. ${ }^{10,24}$ In a dog model of chronic MI, catheter-based injection of these cells led to functional improvement in parallel to increased capillary density despite the absence of cardiac markers in the labeled cells. ${ }^{8}$ Similar beneficial effects were observed in a pig study of acute MI, in which MSC transfer resulted in improved regional and global LV function and reduced infarct size. ${ }^{25}$

It remains unclear which of these cell fractions has the higher regenerative potential in the infarcted myocardium. Only few studies directly compared various cell types. In a porcine model of ischemia and reperfusion, Moelker and colleagues ${ }^{26}$ compared BMNCs with unselected bone marrow. The authors found a greater reduction in infarct size with BMNCs without improvement of regional or global LV function. Kawamato and associates ${ }^{27}$ demonstrated that purified $\mathrm{CD} 34^{+}$cells had better biologic and functional effects than BMNCs, even if the dose of BMNCs was adjusted to contain an equivalent number of $\mathrm{CD} 34^{+}$cells. However, cell injection was performed immediately after coronary ligation, and it is unclear to what extent these data are relevant to the chronically infarcted myocardium. To the best of our knowledge, our study is the first headto-head comparison of BMNCs and culture-expanded MSCs in the setting of chronic MI. In addition to the placebo-controlled and blinded design, we used multimodality functional assessment, including LV Ees, an invasive loadindependent index of cardiac contractility, in a large-animal model of the chronically infarcted myocardium. It is interesting to note that neither therapy had a significant effect on the global and load-dependent indices of LV function. This might be at least partially related to the modest infarction size with mild reduction in global LV ejection fraction. In this setting direct assessment of infarction size by means of MRI might be superior to assessment of ejection fraction in tracking the changes in response to cell therapy. ${ }^{5}$ In this regard our data indicate that myocardial injection of BMNCs is associated with greater improvement in cardiac contractility and regional LV systolic function, reduction of infarct size, and reverse remodeling compared with autologous MSCs. The beneficial effects on both remodeling and function resulted in reduction of NT-proBNP levels. The superior effects of BMNCs were associated with an upregulation of VEGFR2 and TEK expression in parallel with increased arterial density. It is also interesting to note that although nonsignificant trends were observed in SDF1 expression, its message levels correlated with both VEGFR2 and TEK. Given the interplay between $V E G F$ signaling and $S D F 1$ in adult neovascularization, ${ }^{28}$ this suggests that BMNC-induced reversed remodeling and improved performance of the chronically infarcted myocardium might be mediated by a favorable proangiogenic environment and increased neovascularization after BMNC administration. This favorable angiogenic paracrine effect might be attributed in part to the larger amount of $\mathrm{CD} 14^{+}$cells in the nonmodified BMNC fraction and their effects on neovascularization. ${ }^{29}$ Yet the potential effect of BMNC cell delivery on mobilization or recruitment of circulating or tissue-residing progenitors and their contribution to regenerative response should be further addressed.

These observations have several implications for the framework of future preclinical and clinical studies. On the one hand, they support future clinical studies with BMNCs in patients with ischemic cardiomyopathy. On the other hand, they challenge the use of nonmodified MSCs as a cell product for regenerative strategies in the setting of the chronically infarcted myocardium. Although statistically significant, the effect of MSC transfer on regional LV function remained modest and did not translate either into improved contractility or reduction of the infarct size or systemic levels of NT-proBNP. The lack of functional effects might be related to the failure to induce transcriptional activation of angiogenic signaling. Our data are thus in contrast with those of experimental studies showing a reduction in infarct scarring, increased thickness of myocardium, and progressive restoration of contractile function after MSC transplantation. ${ }^{8,25,30}$ These studies mostly used allogenic MSCs, often administered early after the infarction, and recruitment of residing stem cells caused by local inflammatory response has been hypothesized as one of the potential mechanisms underlying the regenerative process. ${ }^{8,25}$ In addition, our model was characterized by a moderate infarct size, and greater benefit from MSCs could be expected in models with more compromised LV function. ${ }^{22,25}$ On the other hand, our data are consistent with those of several studies in which sustained or long-term benefit after injection of MSCs was not observed. ${ }^{10,13,24}$ In addition, the modest effect of nonmodified MSCs supports the development of new strategies to test the hypothesis that guidance of MSCs toward the cardiac lineage might lead to more robust effects on biologic and functional repair after chronic MI. ${ }^{13}$

In conclusion, the present randomized, double-blind, and placebo-controlled with multimodality comparison demonstrates that cell therapy with BMNCs is superior to use of culture-expanded nonmodified MSCs and is associated with reduced infarction size, as well as improved regional function and cardiac contractility, in a canine model of chronic MI. The functional amelioration is associated with a reduction of NT-proBNP level, reverse remodeling, and neovascularization in a proangiogenic environment.

We thank Patrick Broeckaert and Pascale Jespers for excellent technical assistance and Aurore de la Vareille, Philippe Willemsen, and Nancy Ramelot for cell culturing. 


\section{References}

1. Orlic D, Kajstura J, Chimenti S, Jakoniuk I, Anderson SM, Li B, et al. Bonemarrow cells regenerate infarcted myocardium. Nature. 2001;410:701-5.

2. Assmus B, Schächinger V, Teupe C, Britten M, Lehmann R, Döbert N, et al. Transplantation of Progenitor Cells and Regeneration Enhancement in Acute Myocardial Infarction (TOPCARE-AMI). Circulation. 2002;106:3009-17.

3. Strauer BE, Brehm M, Zeus T, Köstering M, Hernandez A, Sorg RV, et al. Repair of infarcted myocardium by autologous intracoronary mononuclear bone-marrow cell transplantation in humans. Circulation. 2002;106:1913-8.

4. Wollert KC, Meyer GP, Lotz J, Ringes-Lichtenberg S, Lippolt P, Breidenbach C, et al. Intracoronary autologous bone-marrow cell transfer after myocardial infarction: the BOOST randomised controlled clinical trial. Lancet. 2004;364:141-8.

5. Janssens S, Dubois C, Bogaert J, Theunissen K, Deroose C, Desmet W, et al. Autologous bone marrow-derived stem-cell transfer in patients with ST-segment elevation myocardial infarction: double-blind, randomised controlled trial. Lancet. 2006;367:113-21.

6. Schächinger V, Erbs S, Elsässer A, Haberbosch W, Hambrecht R, Hölschermann H, et al. Intracoronary bone marrow-derived progenitor cells in acute myocardial infarction. N Engl J Med. 2006;355:1210-21.

7. Lunde K, Solheim S, Aakhus S, Arnesen H, Abdelnoor M, Egeland T, et al. Intracoronary injection of mononuclear bone-marrow cells in acute myocardial infarction. N Engl J Med. 2006;355:1199-209.

8. Silva GV, Litovsky S, Assad JA, Sousa AL, Martin BJ, Vela D, et al. Mesenchymal stem cells differentiate into an endothelial phenotype, enhance vascular density, and improve heart function in a canine chronic ischemia model. Circulation. 2005; 111:150-6.

9. Toma C, Pittenger MF, Cahill KS, Byrne BJ, Kessler PD. Human mesenchymal stem cells differentiate to a cardiomyocyte phenotype in the adult murine heart. Circulation. 2002; 105:93-8

10. Dai W, Hale SL, Martin BJ, Kuang JQ, Dow JS, Wold LE, et al. Allogeneic mesenchymal stem cell transplantation in postinfarcted rat myocardium: short- and long-term effects. Circulation. 2005;112:214-23.

11. Jiang Y, Jahagirdar BN, Reinhardt RL, Schwartz RE, Keene CD, OrtizGonzalez XR, et al. Pluripotency of mesenchymal stem cells derived from adult marrow. Nature. 2002;418:41-9.

12. Di Nicola M, Carlo-Stella C, Magni M, Milanesi M, Longoni PD, Matteucci P, et al. Human bone-marrow stromal cells suppress T-lymphocyte proliferation induced by cellular or nonspecific mitogenic stimuli. Blood. 2002;99:3838-43.

13. Bartunek J, Croissant JD, Wijns W, Gofflot S, de Lavareille A, Vanderheyden M, et al. Pretreatment of adult bone-marrow mesenchymal stem cells with cardiomyogenic growth factors and repair of the chronically infarcted myocardium. Am J Physiol Heart Circ Physiol. 2007;292:H1095-104.

14. Sahn DJ, DeMaria A, Kisslo J, Weyman A. Recommendations regarding quantitation in M-mode echocardiography: results of a survey of echocardiographic measurements. Circulation. 1978;58:1072-83.

15. Schiller NB, Shah PM, Crawford M, De Maria A, Devereux R, Feigenbaum H, et al. Recommendations for quantitation of the left ventricle by two-dimensional echocardiography. American Society of Echocardiography Committee on Stan- dards, Subcommittee on Quantitation of Two-Dimensional Echocardiograms J Am Soc Echocardiogr. 1989;2:358-67.

16. Baan J, van der Velde ET, de Bruin HG, Smeenk GJ, Koops J, van Dijk AD, et al. Continuous measurement of left ventricular volume in animals and humans by conductance catheter. Circulation. 1984;70:812-23.

17. Winer J, Jung CK, Shackel I, Williams PL. Development and validation of realtime quantitative reverse transcriptase-polymerase chain reaction for monitoring gene expression in cardiac myocytes in vitro. Anal Biochem. 1999;270:41-9.

18. Rafii S, Lyden D. Therapeutic stem and progenitor cell transplantation for organ vascularization and regeneration. Nat Med. 2003;9:702-12.

19. Murry CE, Soonpaa MH, Reinecke H, Nakajima H, Nakajima HO, Rubart M, et al. Haematopoietic stem cells do not transdifferentiate into cardiac myocytes in myocardial infarcts. Nature. 2004;428:664-8.

20. Vanderheyden M, Heyndrickx G, Wijns W, Bartunek J. Framework towards optimisation of bone-marrow stem cells therapy for cardiac repair. Eurointervention. 2007;2:B95-8

21. Stamm C, Westphal B, Kleine HD, Petzsch M, Kittner C, Klinge H, et al. Autologous bone-marrow stem-cell transplantation for myocardial regeneration. Lancet. 2003;361:45-6.

22. Perin EC, Dohmann HF, Borojevic R, Silva SA, Sousa AL, Mesquita CT, et al. Transendocardial, autologous bone marrow cell transplantation for severe, chronic ischemic heart failure. Circulation. 2003;107:2294-302.

23. Strauer BE, Brehm M, Zeus T, Bartsch T, Schannwell C, Antke C, et al. Regeneration of human infarcted heart muscle by intracoronary autologous bone-marrow cell transplantation in chronic coronary artery disease: the IACT Study. J Am Coll Cardiol. 2005;46:1651-8.

24. Shake JG, Gruber PJ, Baumgartner WA, Senechal G, Meyers J, Redmond JM, et al. Mesenchymal stem cell implantation in a swine myocardial infarct model: engraftment and functional effects. Ann Thorac Surg. 2002;73:1919-25.

25. Amado LC, Saliaris AP, Schuleri KH, St John M, Xie JS, Cattaneo S, et al. Cardiac repair with intramyocardial injection of allogeneic mesenchymal stem cells after myocardial infarction. Proc Natl Acad Sci U S A. 2005;102:11474-9.

26. Moelker AD, Baks T, van den Bos EJ, van Geuns RJ, de Feyter PJ, Duncker DJ, et al. Reduction in infarct size, but no functional improvement after bone marrow cell administration in a porcine model of reperfused myocardial infarction. Eur Heart J. 2006;27:3057-64.

27. Kawamoto A, Iwasaki H, Kusano K, Murayama T, Oyamada A, Silver M, et al CD34-positive cells exhibit increased potency and safety for therapeutic neovascularization after myocardial infarction compared with total mononuclear cells. Circulation. 2006;114:2163-9.

28. Grunewald M, Avraham I, Dor Y, Bachar-Lustig E, Itin A, Jung S, et al. VEGFinduced adult neovascularization: recruitment, retention, and role of accessory cells. Cell. 2006;124:175-89.

29. Urbich C, Dimmeler S. Endothelial progenitor cells functional characterization. Trends Cardiovasc Med. 2004;14:318-22.

30. Tomita S, Mickle DA, Weisel RD, Jia ZQ, Tumiati LC, Allidina Y, et al. Improved heart function with myogenesis and angiogenesis after autologous porcine bone marrow stromal cell transplantation. J Thorac Cardiovasc Surg. 2002;123:1132-40. 